\title{
Freshwater pond microalgae for biofuel: Strain isolation, identification, cultivation and fatty acid content
}

\author{
BAYU AFNOVANDRA PERDANA ${ }^{\mathbf{1}}$, ABDI DHARMA ${ }^{1, \boldsymbol{\varphi}}$, INDRA JUNAIDI ZAKARIA ${ }^{2}$, SYAFRIZAYANTI ${ }^{1}$ \\ ${ }^{1}$ Department of Chemistry, Faculty of Mathematics and Natural Sciences, Universitas Andalas. Jl. Moh. Hatta, Limau Manih, Padang 25163, West \\ Sumatra, Indonesia. Tel.: +62-751-71671, Fax.: +62-751-73118, `email: abdipogil@gmail.com, bayuafnovandra09@gmail.com \\ ${ }^{2}$ Department of Biology, Faculty of Mathematics and Natural Sciences, Universitas Andalas. Jl. Moh. Hatta, Limau Manih, Padang 25163, West Sumatra, \\ Indonesia
}

Manuscript received: 14 April 2020. Revision accepted: 5 January 2021.

\begin{abstract}
Perdana BA, Dharma A, Zakaria IJ, Syafrizayanti. 2021. Freshwater pond microalgae for biofuel: Strain isolation, identification, cultivation, and fatty acid content. Biodiversitas 22: 505-511. Microalgae have capability to produce fatty acid for biofuel, drugs, and nutraceutical foods development. This study was carried out to obtain a new strain candidate for fatty acid production. The methods were used in this study include isolation of microalgae species from freshwater ponds of Andalas University, Padang, Indonesia. Molecular identification of microalgae was carried out with specific 18S rRNA primer, F-P73, and R-P47. Microalgae growth was measured by cell density and optical density method using various wavelengths $(400,500$, and $680 \mathrm{~nm})$. Total lipid was extracted using Bligh \& Dyer method. Fatty acid analyses were conducted using gas chromatography-mass spectroscopy. Microalgae were isolated i.e Chlorella emersonii MAUA001, Mychonastes rotundus MAUA002, Scenedesmus dimorphus MAUA003, and Scenedesmus armatus MAUA004. The result exhibited M. rotundus was the highest lipid content, it was about $28.8 \%$ biomass weight. Fatty acid profiles of microalgae were dominated by monounsaturated (MUFA) and saturated fatty acid (SFA). The highest content of fatty acid species found in C. emersonii with octadecenoic acid (C18:1) was $47.74 \%$ total lipid. This work showed that $C$. emersonii has potential as biodiesel due to high saturated fatty acid.
\end{abstract}

Keywords: Fatty acids, lipid, microalgae, microalgae isolation, molecular identification

\section{INTRODUCTION}

Microalgae is a photosynthetic microorganism that is able to fix $\mathrm{CO}_{2}$ to produce biomass and has a role as a primary producer in aquatic environment. It has the capability to grow under harsh conditions. Microalgae can be easily cultivated and produced to obtain certain organic material for human necessity, such as biomass, lipid, phycocyanin, astaxanthin, and other useful metabolites. By the year 2004, about 7000 tons of microalgae biomass annually have been produced for market demands (Spolaore et al. 2006). This statistic showed that microalgae have gained popularity among the worldwide industrial productions and will continue to develop utility and trends.

Microalgae have a great diversity that has potential to explore and use as human needs. A conservative approach result estimated the microalgae species about 72500 algal species, about 44000 species have probably been published (Guiry 2012), less than 50 species have been commercially produced by industries (Milledge 2012). Most frequently research topics of microalgae related to biomass, biodiesel, fatty acid, and food due to that topic have high potential and high price for making valuable products (GarridoCardenas et al. 2018). Microalgae have capability to rapid growth and accumulating high oil content rather than other plants. Some microalgae species, such as Botryococcus brauinii have lipid content $65 \%$ of biomass dry weight (Tasić et al. 2016).
Microalgae lipids are appropriate choice to reduce fossil fuel consumption. Fossil fuel consumption will lead the fossil oil reserves to be exhausted in less than 50 years. Besides, fossil fuel is the major greenhouse gasses source responsible for global warming; fossil fuel energy usage should be reduced or limited. Moreover, microalgae oil has high omega-3 fatty acid content, which is good for novel human food development (Topuz 2016). EPA and DHA contents in microalgae oil is able to consume without causing some health risk such as allergy to seafood oil (Martins et al. 2013). Microalgae cultivation and development for biodiesel and food need the appropriate strain to enhance the products. Isolation, identification, and characterization of microalgae growth are important to initiate early microalgae development and production. This study would carry out isolation of some species of freshwater microalgae. The purpose of this research was to obtain the best species for fatty acid production. The new strains would be used for various applications of fatty acid production.

\section{MATERIALS AND METHODS}

\section{Isolation and identification of microalgae}

Microalgae were isolated from freshwater ponds of Andalas University, Padang, West Sumatra, Indonesia using micropipette washing technique (Parvin et al. 2007). The isolated microalgae were then cultivated using Bold 
Basal Medium in $500 \mathrm{~mL}$ flask at temperature $27^{\circ} \mathrm{C}$, light intensity of 2500 lux for 24 hours/day, and aerated using $3.5 \mathrm{~L} / \mathrm{min}$ flow rate. Microalgae were harvested at late exponential phase by centrifugation. The genomics DNA microalgae were isolated using Plant Wizard Genomic DNA Purification Kit (Promega). Extraction procedure was conducted following manufacturer's instruction. The DNA quality was checked using electrophoresis in $0.8 \%$ agarose. The 18S rRNA was amplified using a pair primer, forward F-P73 (5'AATCAGTTATAGTTTAATTGRT'3) and reverse R-P47 (5'TCTCA GGCTCCCTCTC CGGA'3) (Gour et al. 2016). PCR was conducted following the steps; initial denaturation of 4 minutes at $94^{\circ} \mathrm{C}$ followed 35 cycles of denaturation at $94^{\circ} \mathrm{C}$ for 1 minute, primer annealing at $52.5^{\circ} \mathrm{C}$ for 55 seconds, primer extension at $72^{\circ} \mathrm{C}$ for 1 minute, then final extension at $72^{\circ} \mathrm{C}$ for 5 minutes. PCR products were separated using electrophoresis on $1 \%$ agarose. DNA sequencing was conducted using 18S rRNA, then all sequences were compared with GenBank database using BLAST.

\section{Extraction of total lipid and fatty acid analyses by gas chromatography and mass spectroscopy}

Total lipid extraction was conducted using Bligh and Dyer method (Cavonius et al. 2014). Amount of $20 \mathrm{mg}$ of microalgae dry biomass were wetted with $80 \mu \mathrm{L}$ distilled water for $60 \mathrm{~min}$, then added $300 \mu \mathrm{L}$ of chloroform: methanol (1:2), vortex for $2 \mathrm{~min}$. Then, sample was added $100 \mu \mathrm{L}$ of chloroform and vortex for $30 \mathrm{~s}$. Sample was centrifuged at $2500 \times \mathrm{g}$ for $6 \mathrm{~min}$. The water layer was discarded, the chloroform phase recovered, the residue reextracted with $100 \mu \mathrm{L}$ of chloroform three times. Then, the extracts were air-dried and total lipid (TL) percentage was determined by following formula:

$$
\% \mathrm{TL}=\frac{\text { Total lipid weight }(\mathrm{g})}{\text { Total biomass weight }(\mathrm{g})} \times 100 \%
$$

Lipid extracted from microalgae biomass was methylated by modified methanolic $\mathrm{HCl}$-transesterification method Cavonius et al. (2014). Microalgae lipid was incubated at $90^{\circ} \mathrm{C}$ for 2 hours with methanol: $\mathrm{HCl}$ : chloroform (10: 1: 1). Thereafter, lipid was added $1 \mathrm{~mL}$ distilled water and fatty acid methyl ester extracted by adding $2 \mathrm{~mL}$ hexane-chloroform (4: 1), vortexed and top layer recovered. The organic layer was injected to GC-MS with specification were column oven temperature $50^{\circ} \mathrm{C}$, injection temperature $250^{\circ} \mathrm{C}$, pressure $119,3 \mathrm{kPa}$, total flow $60 \mathrm{~mL} / \mathrm{min}$, start time $2.00 \mathrm{~min}$, end time $60.54 \mathrm{~min}$, start $\mathrm{m} / \mathrm{z} 40.00$, and end $\mathrm{m} / \mathrm{z} 500.00$.

\section{RESULTS AND DISCUSSION}

\section{Isolation and identification of microalgae}

Four species of microalgae had been successfully isolated from freshwater ponds of Andalas University. Microalgae were observed under microscope using 400x magnification to revealed morphological characteristics and purity (Figure 1). Result from morphological identification showed that the four species were Chlorella sp.1, Chlorella sp.2, Scenedesmus sp.1, and Scenedesmus sp.2. Morphological identification was used to assist the next molecular identification $\operatorname{pr}^{\circ} \mathrm{C}$ ess to determine the correct primer. Microalgae molecular identification confirmed that Chlorella sp.1 as Chlorella emersonii MAUA001, Chlorella sp.2 as, Mychonastes rotundus MAUA002, Scenedesmus sp3 as Scenedesmus dimorphus MAUA003, and Scenedesmus sp4 as Scenedesmus armatus MAUA004. All microalgae classified as Chlorophyta, Ordo Chlorococcales.

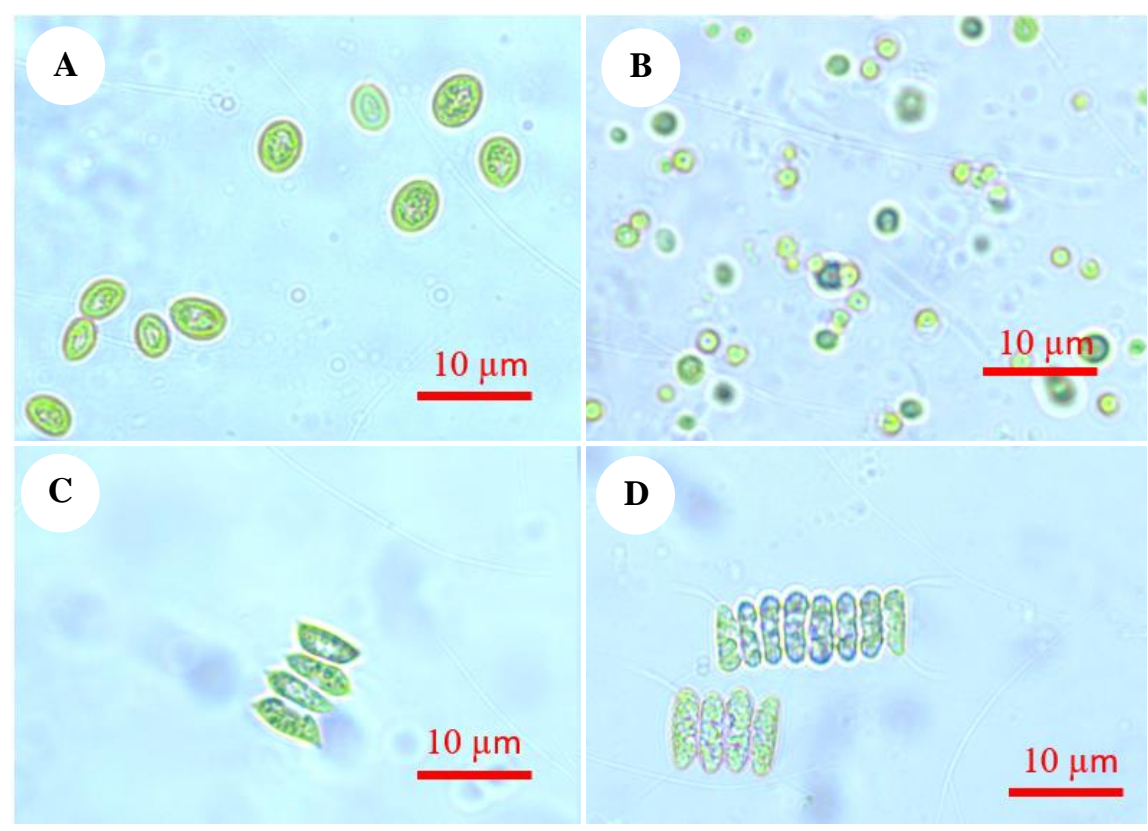

Figure 1. Morphological image using microscope 400x magnification. A. Chlorella emersonii MAUA001; B. Mychonastes rotundus MAUA002; C. Scenedesmus armatus MAUA004; D. Scenedesmus dimorphus MAUA003 


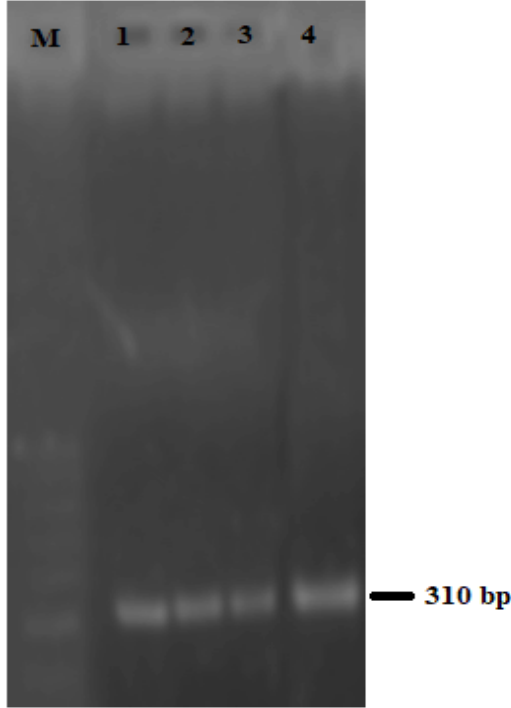

Figure 2. Agarose gel electrophoresis of $18 \mathrm{~S}$ rRNA PCR products. M: Marker, 1: S. dimorphus, 2: C. emersonii, 3: M. rotundus, 4: S.armatus electrophoresis band

Microalgae DNA extracted and amplified by F-P73 and R-P74 primer showed the clear bands (Figure 2). Electrophoresis analyses exhibited the PCR product in amount of $310 \mathrm{bp}$. The PCR products of the samples were then purified and send to sequencing analyses. Microalgae DNA sequences were compared with other related species in GenBank database with $98-99 \%$ sequence similarity and e-value 0.0. Databases were then downloaded, aligned, and constructed using MEGA 6.0 with Neighbor-Joining phylogenetic tree method.

Phylogenetic tree exhibited the bootstrap value 67, 71, 77 and 99 on $S$. dimorphus, C. emersonii, M. rotundus, and $S$. armatus group respectively (Figure 3 ). The bootstrap value highly supported closest relationship between species in each cluster. Bootstrap value is used for determining appropriate model of phylogenetic tree. The higher of bootstrap value is shown then more valid data used and more acceptable the phylogenetic tree model constructed. Conversely, if bootstrap value is lower, the sequence must be removed from analyses so that the phylogenetic tree can be trusted (Dharmayanti 2011). Figure 3 showed that $S$. armatus MAUA004 is the highest bootstrap value between microalgae isolates. $S$ armatus MAUA004 related with Scenedesmus sp KL, Desmodesmus sp Sp.19.010, and S. armatus GonYang4. Likewise the other isolate, the species are grouped in appropriate clusters.

\section{Microalgae growth characteristic}

Microalgae were cultivated using $500 \mathrm{~mL}$ Bold Basal Medium (BBM) for 10 days (about early stationary phase). Growth rates were measured using cell density and optical density (OD) approaches. Growth rate measurements using cell density are shown in Figure 4.A indicated that microalgae exhibited the late logarithmic phase at day 9, except for $S$. dimorphus on day 8. Late logarithmic phase is signed with drastically high increase of cell density and followed by the lower of cell density accretion. In cell division rate, $M$. rotundus have highest cell density among the other microalgae. $M$. rotundus cell at day 10 was $140 \mathrm{x}$ $10^{6} \mathrm{cell} / \mathrm{mL}$. Optical density of microalgae growth was measured using 400, 500, and $680 \mathrm{~nm}$. The choice of those wavelengths aimed to calibrate the appropriate visible wavelength for microalgae growth measurement. At Figure 4.B showed that OD at $400 \mathrm{~nm}$ has highest absorbance value. While, the OD $680 \mathrm{~nm}$ is lower at all microalgae, except $S$. dimorphus after day 6 cultivation.

Optical density was conducted to simplify the continued measurement of microalgae growth rate. Therefore, in this study, the linear regression correlation was used to analyze relationship between the OD wavelengths with cell density. The cell density was chosen as standard for validation OD growth rate measurement. Linear regression correlation coefficient $\left(R^{2}\right)$ value showed in Table $1 . R^{2}$ values range between 0.89-0.99, implicating a high positive relationship between cell density with all OD wavelengths. However, the highest value of $\mathrm{R}^{2}$ was $680 \mathrm{~nm}$ for $M$. rotundus, S.armatus, and S. dimorphus. Meanwhile, C. emersonii has highest $\mathrm{R}^{2}$ value at $500 \mathrm{~nm}$. The highest $\mathrm{R}^{2}$ values indicated the most appropriate wavelength for microalgae growth measurement.

Microalgae cell size exhibited fluctuation along cultivation process. Cell size of $M$. rotundus and $C$. emersonii were measured by diameter of cell. However, $S$. armatus and $S$. dimorphus were measured by the width of cell due to more fluctuative than the length of cell. Microalgae cell size diverse along the time of cultivation. There was no clear pattern between microalgae cell size with cultivation time. The higher microalgae cell size exhibited autospore formation for microalgae cells and the lower showed the microalgae finished division process after autospore form. Standard deviation bar in Figure 5 showed the diverse cell size at one time of measurement. The highest diverse cell size for every species indicated that most active division process of cell occurred before measurement.

\section{Lipid content and fatty acids profile of microalgae}

Microalgae harvested, extracted and total lipid percentage was determined by lipid per biomass weight. Figure 6 showed that lipid content range between 23-28.8\% bw. M. rotundus was the highest lipid content among other microalgae, followed by $S$. dimorphus, C. emersonii, and $S$. armatus. Analyses of variance (ANOVA) were conducted to analyze the significance between the microalgae lipid contents, then followed by Bonferroni post hoc test at significance 0.05 . M. rotundus lipid content has no significant value with $C$. emersonii, but it has a difference with $S$. armatus and $S$. dimorphus. Based on the analysis, $M$. rotundus was the best lipid content for production.

Table 1. Linear regression correlation coefficient $\left(\mathrm{R}^{2}\right)$ relationship between OD and cell density

\begin{tabular}{ccccc}
\hline $\begin{array}{l}\text { Optical } \\
\text { density }\end{array}$ & $\begin{array}{c}\text { M. } \\
\text { rotundus }\end{array}$ & $\begin{array}{c}\boldsymbol{C} \text {. } \\
\text { emersonii }\end{array}$ & $\begin{array}{c}\text { S. } \\
\text { armatus }\end{array}$ & $\begin{array}{c}\text { S. } \\
\text { dimorphus }\end{array}$ \\
\hline $400 \mathrm{~nm}$ & 0.8951 & 0.8806 & 0.8393 & 0.8825 \\
$500 \mathrm{~nm}$ & 0.9732 & 0.9779 & 0.8706 & 0.9155 \\
$680 \mathrm{~nm}$ & 0.9859 & 0.9623 & 0.8908 & 0.9942 \\
\hline
\end{tabular}




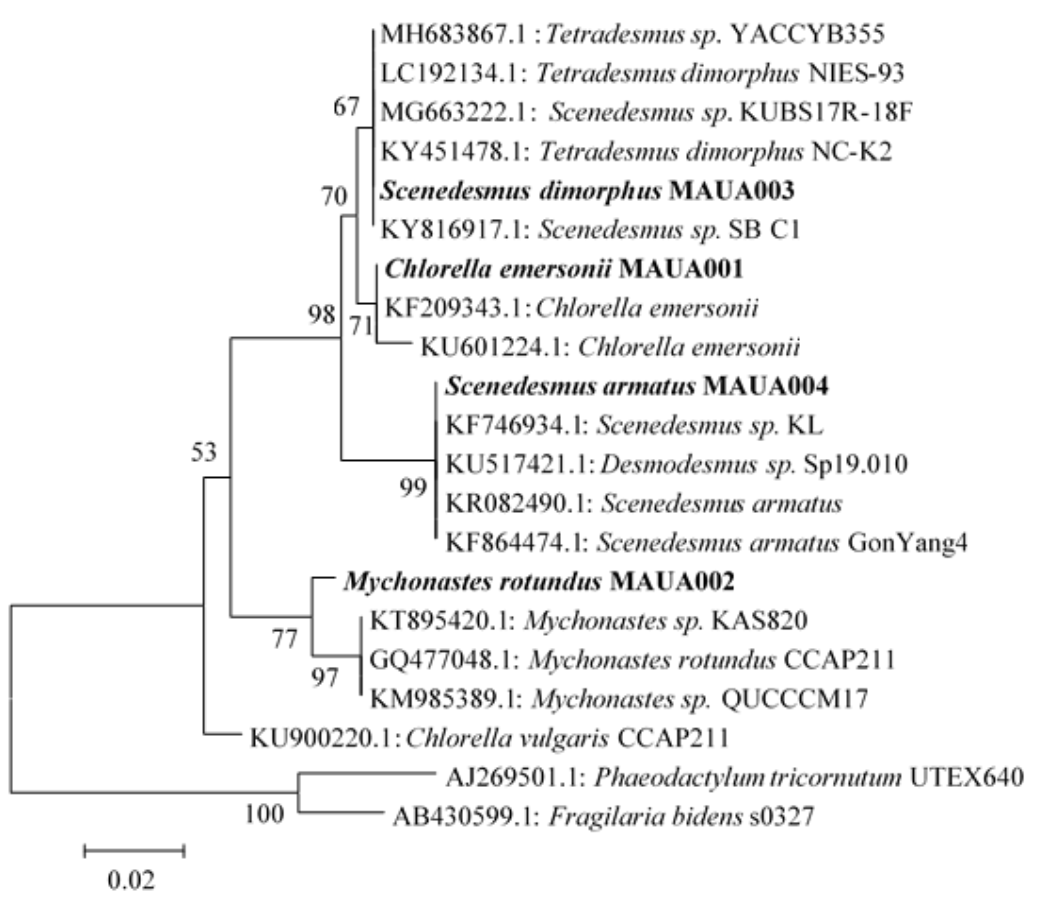

Figure 3. Phylogenetic tree of microalgae constructed using Neighbor-Joining method
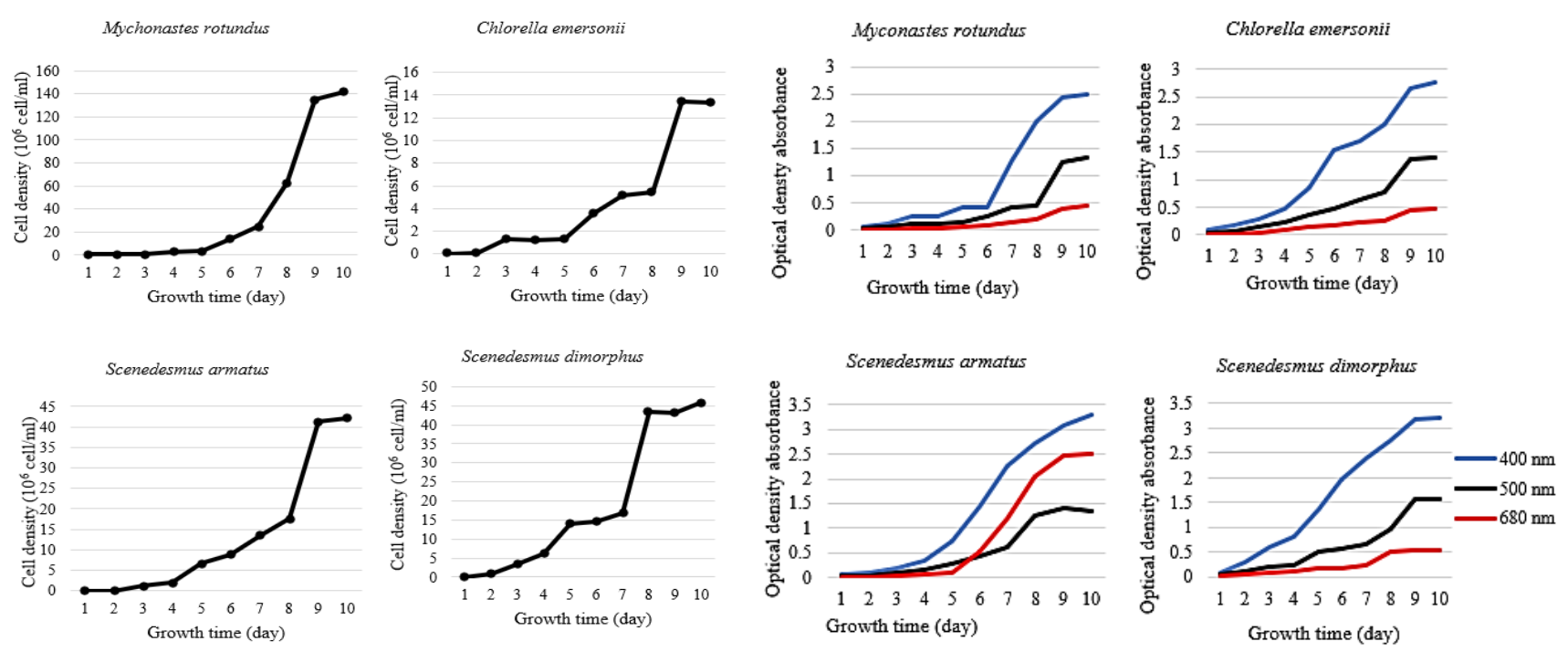

A

\section{B}

Figure 4. Microalgae growth measured by A. Increasing cell density of microalgae; B. Optical density with 400,500 and $680 \mathrm{~nm}$ wavelength
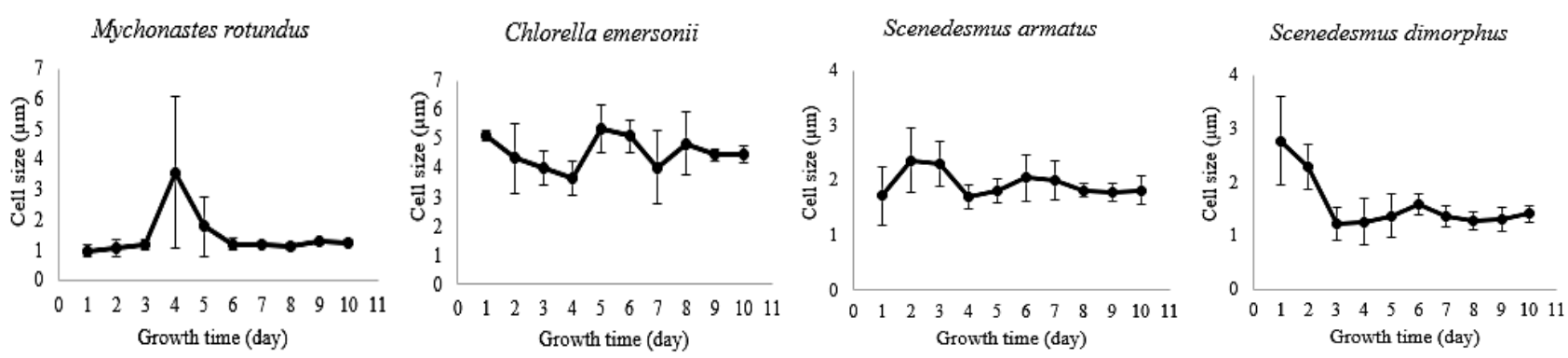

Figure 5. Microalgae cell size and standard deviation bar along cultivation process 
GC-MS analyzed microalgae lipid for fatty acids profile. Table 2 exhibited the kind of fatty acid profile. Total fatty acids were recovered range between 42.17$91.23 \%$ total lipid. The highest total fatty acid was found in $C$. emersonii and the lowest ones in $M$. rotundus. Monounsaturated fatty acid (MUFA) was the highest content of $M$. rotundus, $C$. emersonii dan $S$. dimorphus. Meanwhile, $S$. armatus was dominated by saturated fatty acid (SFA) about $33.47 \%$. Besides MUFA, $M$. rotundus has high polyunsaturated fatty acid (PUFA) and low SFA content. But, $C$. emersonii and $S$. dimorphus had higher SFA contents than PUFA. In terms of fatty acids species, octadecenoic acid (C18:1) was the highest fatty acids content of M. rotundus, C. emersonii, and S. dimorphus. Meanwhile, S. armatus has palmitic acid (C16:0) as the highest content of fatty acids species. Omega fatty acids were found of kind omega-3, omega-6 and omega-12. $M$. rotundus and $C$. emersonii have high omega-6 contents $14.97 \%$ and $13.72 \%$ respectively.

Table 2. Fatty acids profile of microalgae (\% total lipid) of M. rotundus (MR), C. emersonii (CE), S. dimorphus (SD) dan S. armatus (SA)

\begin{tabular}{|c|c|c|c|c|c|}
\hline \multirow{2}{*}{ Fatty acid species } & \multirow{2}{*}{ Formula } & \multicolumn{4}{|c|}{ Fatty acid content (\% TL) } \\
\hline & & MR & $C E$ & $S D$ & $S A$ \\
\hline Hexadecanoic acid/ Palmitic acid & C16:0 & 17.60 & 18.70 & 17.43 & 29.26 \\
\hline Hexadecenoic acid & C16:1 & - & - & - & 2.54 \\
\hline Hexadecadienoic acid & $\mathrm{C} 16: 2$ & 1.31 & 2.58 & - & 0.70 \\
\hline Hexadecatrienoic acid & $\mathrm{C} 16: 3 \omega 3$ & 3.64 & 4.57 & - & - \\
\hline Octadecanoic acid/ Stearic acid & C18:0 & 2.30 & 4.15 & 2.02 & 3.75 \\
\hline Octadecenoic acid & C18:1 & 23.97 & 47.74 & 18.92 & 24.39 \\
\hline Octadecenoic acid omega 12 & $\mathrm{C} 18: 1 \omega 12$ & - & - & 3.80 & 3.72 \\
\hline Octadecadienoic acid & C18:2 & - & - & 8.21 & 9.72 \\
\hline Octadecadienoic acid/ Linoleic Acid & $\mathrm{C} 18: 2 \omega 6$ & 14.97 & 13.72 & - & - \\
\hline Octadecatrienoic acid/Methyl $\gamma$-linolenate & $\mathrm{C} 18: 3 \omega 6$ & - & - & - & 0.43 \\
\hline Eicosatrienoic acid & C20:3 & - & 0.40 & - & - \\
\hline Docosanoic acid/ Behenic acid & $\mathrm{C} 22: 0$ & - & - & - & 0.46 \\
\hline Total FA & & 42.17 & 91.86 & 50.38 & 74.57 \\
\hline SFA & & 18.20 & 22.85 & 19.45 & 33.47 \\
\hline MUFA & & 23.97 & 47.74 & 22.72 & 30.65 \\
\hline PUFA & & 19.92 & 21.27 & 8.21 & 10.85 \\
\hline Omega-3 & & 3.64 & 4.75 & - & - \\
\hline Omega 6 & & 14.97 & 13.72 & - & 0.43 \\
\hline Omega 12 & & - & - & 3.80 & 3.72 \\
\hline
\end{tabular}

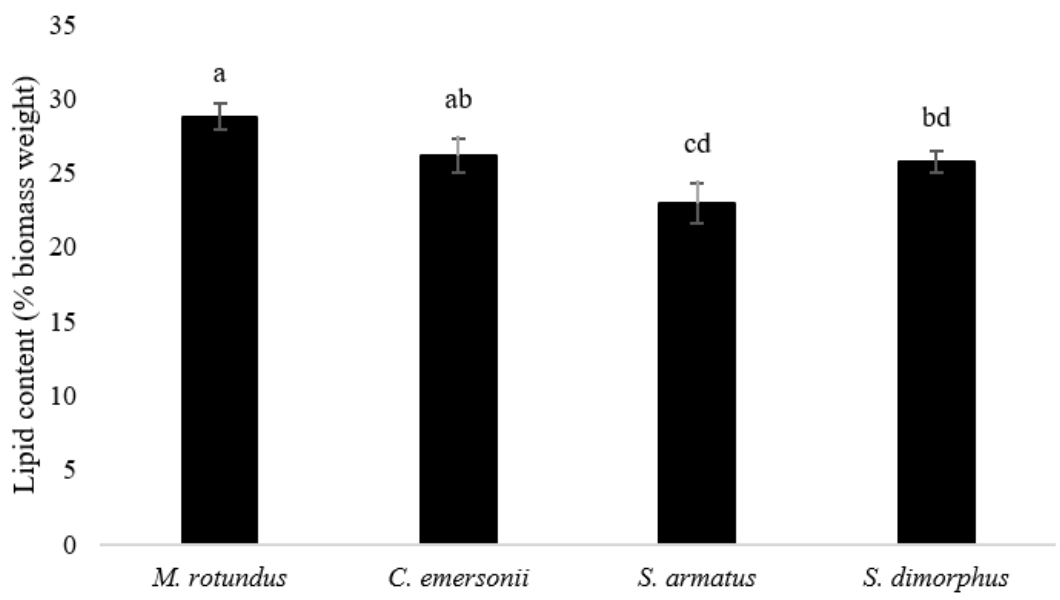

Figure 6. Microalgae lipid contents extracted by Bligh Dyer method. The superscript letter above the bar lipid content showed the significant value by ANOVA analyses with Bonferroni post hoc test at significance 0.05 


\section{Discussion}

Microalgae were isolated and observed using microscope exhibited clear morphological differences. $M$. rotundus and C. emersonii have same coccoid form, but the differences between them both were cell size of $C$. emersonii is larger than that of $M$. rotundus. C. emersonii cell size was 5-7 $\mu \mathrm{m}$ while $M$. rotundus 1-3 $\mu \mathrm{m}$ (Figure 5). Mychonastes and Chlorella were one group of Chlorella genus due to the similarities of their morphological characteristic (Krienitz et al. 2011). S. armatus and S. dimorphus have a clearly different morphological characteristics in present of cetae or spine in tip of $S$. armatus cenobium. S. armatus cenobia was ovoid rounded while $S$. dimorphus ovoid pointed. All of morphological characteristics were suited with identification book (Yamaji 1980). Molecular identification was conducted for validation and observation of closest relationship between the previous databases. DNA extraction and amplification using specific 18S rRNA primer, F-P73 and R-P47 exhibited $310 \mathrm{bp}$ in electrophoresis result. The PCR product was a bit larger than previous study was conducted by Gour et al. (2016) with PCR product 270-276 bp for Chlorella and Scenedesmus microalgae.

Microalgae growth exhibited a high increase in cell density over time. M. rotundus has highest cell density $\left(140 \times 10^{6} \mathrm{cell} / \mathrm{ml}\right.$ at day 10) among the microalgae isolates. The $M$. rotundus cell density was higher than previous researches (Šoštariè et al. 2009; Chia et al 2013). Bold Basal medium was used in this study suited for microalgae isolates growth. Wong et al. (2017) has reported about microalgae medium for cultivation. The Bold Basal medium was the best growth medium among the other twelve growth mediums (M-8, BG 11 modified, Spirulina medium modified, N-8, BG 11, RM, Chu modified, Johnson, F/2, Fog, and Fog medium without nitrogen).

Microalgae lipid content ranged between 23-28.8\% were classified as adequate if compare to previous research. Commonly, microalgae lipid content ranged between 10-50\% biomass weight ( $\mathrm{Xu}$ and $\mathrm{Hu}$ 2013; Ramluckan et al. 2014; Tan et al. 2018; Chi et al. 2019). The difference of microalgae lipid contents depends on microalgae strain, cultivation treatment, and lipid extraction process. Microalgae fatty acid profile showed various types of fatty acid. Based on the common usage of microalgae fatty acid, the microalgae have potential as biodiesel and food production in this study. Some microalgae have high content of SFA and MUFA such as C. emersonii were potential for biodiesel production. $C$. emersonii were dominated by $\mathrm{C} 18: 1$ which has $57.74 \%$ total lipid content. Besides, C. emersonii and M. rotundus have high PUFA contents that have potential as food production.

In conclusion, microalgae isolation and fatty acid profiling were obtained. Microalgae isolate for fatty acid production was successfully isolated. Lipid content of $M$. rotundus was the highest obtain of all other isolates. Fatty acid profiles of microalgae were dominated by monounsaturated (MUFA) and saturated fatty acid (SFA).
The highest content of fatty acid species was found in $C$. emersonii with octadecenoic acid (C18:1) content was $57.74 \%$ total lipid. Based on application purpose, $C$. emersonii has potential as biodiesel and M. rotundus as nutraceutical food.

\section{ACKNOWLEDGEMENTS}

The author would like to gratefully acknowledge to DIKTI who was financially support via PMDSU research grant year 2018/2019.

\section{REFERENCES}

Cavonius LR, Carlsson N, Undeland I. 2014. Quantification of total fatty acids in microalgae: Comparison of extraction and transesterification methods. Anal Bioanal Chem 406 (28): 7313-7322. DOI: 10.1007/s00216-014-8155-3.

Chi NTL, Duc PA, Mathimani T, Pugazhendhi A. 2019. Evaluating the potential of green alga Chlorella sp. for high biomass and lipid production in biodiesel viewpoint. Biocat Agric Biotechnol 17: 184188. DOI: 10.1016/j.bcab.2018.11.011.

Chia MA, Lombardi AT, Melao MG. 2013. Growth and biochemical composition of Chlorella vulgaris in different growth media. An Acad Bras Ciênc 85 (4): 1427-1438. DOI: 10.1590/00013765201393312 .

Dharmayanti I. 2011. Filogenetika molekuler: Metode taksonomi organisme berdasarkan sejarah evolusi. Wartazoa 21 (1): 1-10.

Garrido-Cardenas JA, Manzano-Agugliaro F, Acien-Fernandez FG, Molina-Grima E. 2018. Microalgae research worldwide. Algal Res 35: 50-60. DOI: 10.1016/j.algal.2018.08.005.

Gour RS, Chawla A, Singh H, Chauhan RS, Kant A. 2016. Characterization and screening of native Scenedesmus sp. isolates suitable for biofuel feedstock. PLoS One J 11: 1-16. DOI: 10.1371/journal.pone.0155321.

Guiry MD. 2012. How many species of algae are there?. J Phycol 48: 1057-1063. DOI: 10.1111/j.1529-8817.2012.01222.x.

Krienitz L, Bock C, Dadheech PK, Pröschold T. 2011. Taxonomic reassessment of the genus Mychonastes (Chlorophyceae, Chlorophyta) including the description of eight new species. Phycologia 50: 89-106. DOI: 10.2216/10-15.1.

Martins DA, Custodio L, Barreira L, Pereira H, Hamadou RB, Varela J, Salah KMA. 2013. Alternative source of n-3 long-chain polyunsaturated fatty acids in marine microalgae. Mar Drug 11 (7): 2259-2281. DOI: $10.3390 / \mathrm{md} 11072259$.

Milledge JJ. 2012. Microalgae-commercial potential for fuel, food and feed. Food Sci Technol 26 (1): 28-30.

Parvin M, Zannat MN, Habib MAB. 2007. Two important techniques for isolation of microalgae. Asian Fish Sci 20: 117-124.

Ramluckan K, Moodley KG, Bux F. 2014. An evaluation of the efficacy of using selected solvents for the extraction of lipids from algal biomass by the soxhlet extraction method. Fuel 116: 103-108. DOI: 10.1016/j.fuel.2013.07.118

Šoštariè M, Golob J, Bricelj M, Klinar D, Pivec A. 2009. Studies on the growth of Chlorella vulgaris in culture media with different carbon sources. Chem Biochem Eng Quart 23 (4): 471-477.

Spolaore P, Joannis-Cassan C, Duran E, Isambert A. 2006. Commercial applications of microalgae. J Biosci Bioeng 101 (2): 87-96.

Tan XB, Lam MK, Uemura Y, Lim JW, Wong CY, Ramli A, Kiew PL, Lee KT. 2018. Semi-continuous cultivation of Chlorella vulgaris using chicken compost as nutrients source: Growth optimization study and fatty acid composition analysis. Energy Conv Manag 164: 363373. DOI: 10.1016/j.enconman.2018.03.020.

Tasić MB, Pinto LFR, Klein BC, Veljković VB, Filho RM. 2016. Botryococcus braunii for biodiesel production. Renew Sust Energy Rev 64: 260-270. DOI: 10.1016/j.rser.2016.06.009.

Topuz OK. 2016. Algal oil: A novel source of omega-3 fatty acids for human nutrition. Sci Bull Ser F Biotechnol 20: 178-183. 
Wong YK, Ho YH, Leung HM, Yung KKL. 2017. Growth medium screening for Chlorella vulgaris growth and lipid production. J Aquac Mar Biol 6 (1): 00143. DOI: 10.15406/jamb.2017.06.00143.
Xu J, Hu H. 2013. Screening high oleaginous Chlorella strains from different climate zones. Bioresour Technol 144: 637-643. DOI: 10.1016/j.biortech.2013.07.029.

Yamaji I. 1980. Illustration of the Freshwater Plankton of Japan. Hoikusha Publishing, Japan. 